\title{
Genome-wide microarray evidence that 8-cell human blastomeres over-express cell cycle drivers and under-express checkpoints
}

\author{
Ann A. Kiessling - Ritsa Bletsa - Bryan Desmarais • \\ Christina Mara • Kostas Kallianidis • Dimitris Loutradis
}

Received: 7 January 2010 /Accepted: 4 March 2010 / Published online: 1 April 2010

(C) The Author(s) 2010. This article is published with open access at Springerlink.com

\begin{abstract}
Purpose To understand cell cycle controls in the 8-Cell human blastomere.

Methods Data from whole human genome (43,377 elements) microarray analyses of RNAs from normal 8-Cell human embryos were compiled with published microarrays of RNAs from human fibroblasts, before and after induced pluripotency, and embryonic stem cells. A sub database of 3,803 genes identified by high throughput RNA knock-down studies, plus genes that oscillate in human cells, was analyzed. Results Thirty-five genes over-detected at least 7-fold specifically on the 8-Cell arrays were enriched for cell cycle drivers and for proteins that stabilize chromosome cohesion and spindle attachment and limit DNA and centrosome replication to once per cycle.

Conclusions These results indicate that 8-cell human blastomere cleavage is guided by cyclic over-expression
\end{abstract}

Capsule Over-expression of cell cycle drivers and lack of checkpoints render 8-Cell human blastomeres susceptible to genetic and chromosomal mishaps.

Electronic supplementary material The online version of this article (doi:10.1007/s10815-010-9407-6) contains supplementary material, which is available to authorized users.

A. A. Kiessling $(\bowtie) \cdot$ B. Desmarais

Bedford Stem Cell Research Foundation,

206 Elm St, Suite 106,

Somerville, MA 02144, USA

e-mail: kiessling@bedfordresearch.org

R. Bletsa $\cdot$ C. Mara $\cdot$ K. Kallianidis $\cdot$ D. Loutradis

1st Department of Obstetrics and Gynecology,

Athens Medical School, "Alexandra” Maternity Hospital,

Athens, Greece

D. Loutradis

e-mail: loutradi@otenet.gr of key proteins, rather than canonical checkpoints, leading to rapidly increasing gene copy number and a susceptibility to chromosome and cytokinesis mishaps, well-noted characteristics of preimplantation human embryos.

Keywords Aurora kinase - Cell cycle · CLOCK · Cyclins · Human embryo $\cdot$ RB

\section{Introduction}

The human blastomere at the 8-cell stage of embryo development is a unique, totipotent cell. Despite the fundamental importance to human reproduction, little is known about cellular controls on gene expression and chromosome duplication in 8-Cell stage human blastomeres. Understanding cell cycle regulation in the 8-Cell is urgently needed to improve outcomes of assisted reproduction and provide insights into the cellular machinery used by the egg to reprogram nuclei from differentiated to totipotent. This information may markedly improve the efficiency of reprogramming unfertilized oocytes and somatic cells to patientspecific stem cells for research and therapy.

We recently reported that RB, the key G1 cell cycle checkpoint, and WEE1, a key G2 cell cycle checkpoint, were silent on microarrays of two pools of normal appearing 8-Cell stage human embryos, whereas MYC and circadian oscillators CLOCK, CRY and PER were markedly elevated [1]. Rb maintains cell cycle arrest in G1 by binding the E2F transcription factors needed for progression through G1 and the initiation of S phase. To overcome the $\mathrm{Rb}$ blockade, growth factors stimulate expression of CyclinD, which binds Cdk4/6 and phosphorylates $\mathrm{Rb}$ in a couple of locations, causing the release of E2F transcription factors that stimulate expression of 
Cyclin E, which binds Cdk2 and phosphorylates Rb again, rendering it inactive. Loss of functional $\mathrm{Rb}$, the first tumor suppressor gene discovered, is a characteristic of many human cancers [2], suggesting that understanding cell cycle regulation in the 8-Cell may also provide unique insights into malignant transformation. Mouse fibroblasts depleted of $\mathrm{Rb}$ become growth factor-independent [3], as are early cleavage stage blastomeres $[4,5]$, which suggests the silence of RB, also reported for early cleaving mouse embryos [6], may be characteristic of totipotent embryo cells, reflecting the lack of a need for cell growth because of their large size. Like other mammals, early human embryo cell cycles are cleavage divisions that halve the volume of daughter blastomeres. Approximately six cleavage divisions, to the 64-cell stage, are needed to reduce the size of the 120 micron diameter human egg to the 10 to 20 micron diameter of normal somatic cells and embryonic stem cells (discussed in [7]).

Consistent with the absence of $\mathrm{Rb}, \mathrm{CCNE}$ was markedly elevated on the microarrays of the 8-Cells [1]. In addition to activating Cdk2, Cyclin E has Cdk2-independent functions, including regulating centrosome duplication [8]. CDK2 knock-out mice are viable, presumably because Cyclin $\mathrm{E}$ can also bind Cdk1, but CCNE knock-out mice die in utero [9]. Cyclin E promotes cell division, and over-expression promotes aneuploidy, as has been observed for numerous human malignancies, although the mechanisms by which Cyclin E induces tumorigenesis remain elusive [10]. The silence of Wee1, the G2 checkpoint kinase that blocks cell division by inhibiting $\mathrm{CyclinB} / \mathrm{Cdk} 1$ [11], suggests that Cyclin E driven aneuploidy may go unchallenged at the G2/ $\mathrm{M}$ transition in the 8-Cell embryo. This may help explain the heteroploidy observed in early human and non-human primate embryo blastomeres [12-14]. But given the fundamental importance to development of accurate chromosome duplication and allocation to daughter blastomeres, the absence of G1 and G2 checkpoints was a surprise. The over-expression of circadian oscillators in the 8-Cells [1] suggests they may help regulate the blastomere cell cycle, as has been demonstrated for many cell types, including mouse liver and muscle [15], rat fibroblasts [16] and human bone marrow [17]. By regulating WEE1 expression through its E-Box elements, mouse liver cell oscillators ensure mitosis is coupled to their circadian cycle [18].

The silence of WEE1 on the 8-Cell microarrays indicates this is not, however, a mechanism used by blastomeres. Moreover, despite recent evidence that circadian oscillators are over-expressed in the 8 Cells, and expression of Per is stimulated at fertilization of zebra fish eggs, heralding the onset of circadian oscillations in zebrafish embryos [19], cell division occurs at intervals much shorter than $24 \mathrm{~h}$ in early embryo cells, including human. In vivo developed mouse blastocysts reach 250 cells, eight cell doublings, by the time of implantation 5 days after fertilization, an average cell cycle time of $15 \mathrm{~h}$, not $24[4,20]$. This is accomplished by cell cycle times of 8 to $12 \mathrm{~h}$ for the 4 - to 16-cell stages, with earlier and later stages closer to $24 \mathrm{~h}$, suggesting some stages are circadian intervals, but others undergo two or three cleavage divisions in one circadian interval. Similar data are not available for human embryos developing in vivo, but in vitro development to at least the 8-cell stage is also less than $24 \mathrm{~h}$ per cell cycle, especially for those embryos thought to be the most likely to produce offspring [21].

If the absence of G1 and G2 checkpoints accounts for rapid cell cycles in the human blastomeres, what safeguards are in place to ensure the integrity of chromosomal duplication and allocation to daughter blastomeres? Is it possible that to allow the production of sufficient embryonic proteins to signal the mother to maintain a receptive uterus, gene copy number is more important in early embryo development than accurate chromosome allocation to daughter cells? Evidence suggests that only one or two of the first 16 cells of the mouse morula give rise to the inner cell mass (ICM), which will become the embryo; the remainder of the cells become trophoblast which gives rise to placenta. Perhaps accurate chromosome allocation first becomes essential to development in the ICM, suggesting that cell cycle checkpoints first appear in ICM cells, perhaps concomitant with the need for growth factors to increase cell size, and that the cell death commonly observed in human blastocysts developed in vivo or in vitro $[22,23]$ reflects the elimination of defective cells, as noted for frog embryos at the midblastula transition [24].

To better understand the cell cycle in the 8-Cell human embryo, we compiled a gene data set from published high throughput strategies not feasible with human embryos that correlate cell morphology and DNA content with expression of cell cycle and cycling genes [25-27]. The compiled gene list corresponds to 3,803 gene elements in our database (8CFES) of whole human genome microarrays of four cell types: 8-Cell embryos, fibroblasts before and after induced pluripotency (iPS cells) and two lines of human embryonic stem (hES) cells (Supplemental Table 1S). We then took advantage of two recent reports of MYC transcriptome [28, 29] to assess the role of the over-expression of MYC in the 8Cells. We report here the results of this analysis which add several gene elements to cell cycle regulation, and reveal unique gene expression characteristics of the 8-Cell human blastomere.

\section{Methods and materials}

Embryos were donated by couples undergoing infertility treatment at Alexandra Hospital in Athens Greece, as described [1,30]. The study protocol was reviewed and approved by the ethics advisory board and human subjects research committees of Alexandra Hospital and Bedford 
Research Foundation. Briefly, three embryos were selected for transfer $48 \mathrm{~h}$ following egg collection. Supernumary embryos were cultured an additional $24 \mathrm{~h}$, and normal appearing, unfragmented, 8-Cell embryos were transferred to microfuge tubes in $2 \mathrm{ul}$ of culture medium and flash frozen in liquid nitrogen for RNA extraction. A total of ten 8-Cell stage embryos from nine couples, divided into two pools of five each were used for microarray analyses. Seven of the nine couples achieved a pregnancy.

RNAs were isolated and amplified for fluorescent probe labeling and hybridization to Agilent whole genome microarrays as described [1]. Briefly, RNAs were isolated with Arcturus PicoPure according to manufacturer's instructions, examined for ratios of $18 \mathrm{~S}$ and $28 \mathrm{~S}$ RNAs with an Agilent Bioanalyzer to assess RNA integrity, and polyadenylated RNAs were amplified to microgram quantities according to a previously reported protocol [31] shown to be linear. Microarray hybridization was done by MoGene, St. Louis, $\mathrm{MO}$, and the raw hybridization intensities normalized by Agilent Feature Extraction Software. The hybridization results were verified for standard RT-PCR housekeeping genes as described [1], and combined into a Filemaker Pro database with microarray data posted at GEO (NCBI) for fibroblast RNAs before and after induced pluripotency [32] and two human embryonic stem cell lines, H9 and HES01 [33], aligned by Agilent feature number [1]. Normalized array data for each gene element were statistically compared to develop guidelines for over- and under-detection [1]. The ratio between the two pools of 8Cell embryos of fluorescence values for each gene element was 1.0 13.0 [1]. For purposes of this report, two standard deviations ( \pm 7 -fold) of the mean ratios of gene element fluorescent detection among the arrays was taken as the threshold for designation of over- or under-detection, as described [1].

Gene lists were submitted to DAVID (david.abcc.ncifcrf. gov) and Reactome (www.reactome.org) for function and ontology analyses, and hand annotated for accuracy. Because of the silence of canonical checkpoint genes, such as RB and WEE1, and the over-detection of unusual cyclins, such as Cyclin A1, standard pathway analysis tools were not relied upon.

\section{Results and discussion}

A comprehensive list of genes important to cell division was compiled from three published studies of high throughput analyses of cultured cells not possible with human embryos. U20S cells, a well studied osteosarcoma cell line, were cultured with small interfering RNA (siRNA) targeting 34,373 human genes [27]. Automated single-cell fluorescence microscopy gathered data for each siRNA: cell number; percentage of cells in G1, S and G2/M; percentage of cells with $>8 \mathrm{~N}$ hyperploidy; and percentage of cells with cytokinetic defects. Depletion of 1,152 gene transcripts strongly affected cell-cycle progression. HeLa cells were cultured with endoribonuclease-prepared short interfering RNAs (esiRNAs) targeting 17,828 genes, followed by propidium iodide staining and flow cytometry analysis of DNA content [26]. Seven parameters were extracted from the DNA content analysis: G1, S, G2/M, 8N (polyploid), 4 $8 \mathrm{~N}$ (aneuploid), percent dead cells, plus mitotic index and cell size. This approach identified 1,351 genes involved in the HeLa cell cycle. RNAs were isolated for microarray analysis at $2 \mathrm{~h}$ intervals following synchronization of early passage human foreskin fibroblasts [25]; 480 cycling genes were identified.

The 3,803 gene elements in 8CFES (Supplemental Table S1) that corresponded to all the genes identified by the three studies DAVID-mapped to 2,377 genes, only 256 of which were designated GO term "cell cycle." Differential expression of the genes identified in each study is described in more detail in supplementary material (Tables S1-S3). Only 122 gene elements identified by the U2OS cell knockdown studies were also identified by one of the other studies, only 186 gene elements identified by the HeLa cell studies corresponded to elements in one of the other two studies, and only 136 of the cycling fibroblast genes corresponded to genes identified in the U2OS or HeLa cells. This striking lack of agreement among the three studies undoubtedly reflects experimental differences, but may more importantly emphasize the cell-type specificity of cell cycle control and the functional redundancy of many genes.

Genes in U20S and HeLa identified by RNA knock-down and cycled in fibroblasts

Only nineteen genes were identified by all three studies (Table S3), which meant they registered a phenotype in both U2OS and HeLa [26, 27] and their expression also cycled in the primary fibroblasts [25]. Seventeen were DAVID-annotated cell cycle (Table 1), and 12 were reported to be Myc targets [28, 29], which did not predict elevated levels of detection on the 8-Cell arrays. Interestingly, none brought about a cell cycle block in G1 and only two (CDC2 and PLK1) brought about a block in G2. This supports the cell-type specificity of gene expression needed for progression through G1 and G2.

Knock-down of eight of the cycling genes blocked HeLa and U20S in S phase, including WEE1, which was a surprise because although it is known that Wee1 phosphorylation of Cdk can arrest DNA-damaged cells in both S and $\mathrm{G} 2$, a role for Wee1 in normal progression through $\mathrm{S}$ phase has not been described. Three of the eight genes were overdetected in 8-Cells and hES cells relative to fibroblasts 
Table 1 Detection levels of genes on 8CFES arrays

\begin{tabular}{|c|c|c|c|c|c|c|c|c|}
\hline \multirow[t]{2}{*}{ Cell cycle stage } & \multirow[t]{2}{*}{ Gene name } & \multirow[t]{2}{*}{${ }^{\mathrm{a}} \mathrm{CC}$} & \multirow[t]{2}{*}{${ }^{\mathrm{b}} \mathrm{M}$} & \multicolumn{4}{|c|}{ Microarray fluorescence units } & \multirow[t]{2}{*}{ Entrez gene ID } \\
\hline & & & & 8 Cell (Ave) & Fibro & iPS & hES (Ave) & \\
\hline \multicolumn{9}{|c|}{ Detected in U2OS and HeLa and cycle in primary fibroblasts } \\
\hline $\mathrm{S}$ & CDC6 & $\mathrm{y}$ & $\mathrm{x}$ & 8,735 & 281 & 3,165 & 6,673 & 990 \\
\hline $\mathrm{S}$ & CHAF1A & $\mathrm{y}$ & & 15,120 & 1,162 & 7,100 & 12,999 & 10036 \\
\hline S & RRM2 & $\mathrm{y}$ & $\mathrm{x}$ & 18,568 & 1,063 & 2,986 & 3,072 & 6241 \\
\hline S & SLBP & & $\mathrm{x}$ & 31,828 & 6,272 & 4,242 & 5,342 & 7884 \\
\hline S & WEE1 & $\mathrm{y}$ & $\mathrm{x}$ & 61 & 180 & 652 & 1,223 & 7465 \\
\hline G2 & $\mathrm{CDC} 2$ & $\mathrm{y}$ & & 8,742 & 910 & 3,930 & 5,789 & 983 \\
\hline $\mathrm{G} 2$ & PLK1 & $\mathrm{y}$ & & 42,907 & 1,973 & 8,069 & 14,937 & 5347 \\
\hline $\mathrm{M}$ & AURKB & $\mathrm{y}$ & & 10,493 & 136 & 956 & 882 & 9212 \\
\hline M & CDCA8 & $\mathrm{y}$ & $\mathrm{x}$ & 36,169 & 2,787 & 6,010 & 9,599 & 55143 \\
\hline M & ESPL1 & $\mathrm{y}$ & $\mathrm{x}$ & 5,912 & 476 & 2,562 & 3,227 & 9700 \\
\hline M & FBXO5 & $\mathrm{y}$ & $\mathrm{x}$ & 10,661 & 367 & 1,064 & 2,620 & 26271 \\
\hline M & SFRS3 & & $\mathrm{x}$ & 35,161 & 23,423 & 42,175 & 68,725 & 6428 \\
\hline M & TPX2 & $\mathrm{y}$ & & 21,321 & 1,505 & 3,037 & 5,854 & 22974 \\
\hline \multicolumn{9}{|c|}{ Detected in $\mathrm{U} 2 \mathrm{OS}$ and $\mathrm{HeLa}$} \\
\hline G1 & CUL2 & $\mathrm{y}$ & & 3,696 & 385 & 308 & 573 & 8453 \\
\hline G1 & $\mathrm{KCNH} 5$ & & & 5,949 & 2 & 3 & 19 & 27133 \\
\hline $\mathrm{S}, \mathrm{G} 1$ & RKHD2 & & $\mathrm{x}$ & 7,737 & 34 & 127 & 120 & 51320 \\
\hline M & CYB561D1 & & & 13,547 & 368 & 254 & 4,617 & 284613 \\
\hline M & INCENP & $\mathrm{y}$ & $\mathrm{x}$ & 8,945 & 241 & 622 & 1,812 & 3619 \\
\hline M & PLXNA1 & & & 242 & 6,425 & 4,546 & 5,157 & 5361 \\
\hline M,G1 & CRKRS & & $\mathrm{x}$ & 3,645 & 64 & 96 & 248 & 51755 \\
\hline M,G1 & WIPI1 & & & 156 & 17,639 & 1,211 & 2,071 & 55062 \\
\hline \multicolumn{9}{|c|}{ Detected in U2OS and cycle in primary fibroblasts } \\
\hline G1 & BUB1 & $\mathrm{y}$ & $\mathrm{x}$ & 7,848 & 443 & 3,955 & 5,369 & 699 \\
\hline $\mathrm{S}$ & GINS2 & $\mathrm{y}$ & & 31,973 & 963 & 5,092 & 7,624 & 51659 \\
\hline $\mathrm{S}$ & KIFC1 & $\mathrm{y}$ & $\mathrm{x}$ & 13,939 & 119 & 700 & 1,772 & 3833 \\
\hline $\mathrm{G} 2$ & CABYR & & & 10,963 & 399 & 1,040 & 1,162 & 26256 \\
\hline $\mathrm{G} 2$ & CDKN1B & $\mathrm{y}$ & & 37 & 773 & 595 & 680 & 1027 \\
\hline M & BARD1 & $\mathrm{y}$ & $\mathrm{x}$ & 8,486 & 515 & 1,836 & 2,453 & 580 \\
\hline M & $\mathrm{CDC} 25 \mathrm{~B}$ & $\mathrm{y}$ & & 28,304 & 4,449 & 538 & 1,061 & 994 \\
\hline M & PRKD2 & & & 9,218 & 597 & 859 & 2,278 & 25865 \\
\hline $\mathrm{M}$ & REEP4 & & & 4,258 & 449 & 281 & 621 & 80346 \\
\hline \multicolumn{9}{|c|}{ Detected in HeLa and cycle in primary fibroblasts } \\
\hline G1 & CCNE1 & $\mathrm{y}$ & $\mathrm{x}$ & 102,960 & 1,596 & 8,037 & 13,034 & 898 \\
\hline G1 & HJURP & & & 11,644 & 357 & 1,430 & 2,133 & 55355 \\
\hline G1 & NEK2 & $\mathrm{y}$ & $\mathrm{x}$ & 2,792 & 245 & 595 & 665 & 4751 \\
\hline G1 & RBBP6 & $\mathrm{y}$ & & 22,492 & 72 & 226 & 260 & 5930 \\
\hline $\mathrm{S}$ & BUB1B & $\mathrm{y}$ & $\mathrm{x}$ & 17,028 & 439 & 3,941 & 6,268 & 701 \\
\hline $\mathrm{S}$ & LMNB2 & & $\mathrm{x}$ & 221 & 937 & 1,681 & 5,232 & 84823 \\
\hline $\mathrm{S}$ & NPAT & $\mathrm{y}$ & & 2,058 & 66 & 206 & 375 & 4863 \\
\hline $\mathrm{S}$ & PCNA & $\mathrm{y}$ & $\mathrm{x}$ & 84,348 & 5,278 & 11,990 & 17,444 & 5111 \\
\hline $\mathrm{G} 2$ & DTL & $\mathrm{y}$ & $\mathrm{x}$ & 5,010 & 250 & 1,614 & 3,345 & 51514 \\
\hline G2 & H1F0 & $\mathrm{y}$ & & 10,711 & 943 & 344 & 1,098 & 3005 \\
\hline $\mathrm{G} 2$ & TIPIN & $\mathrm{y}$ & $\mathrm{x}$ & 7,815 & 1,060 & 3,315 & 4,746 & 54962 \\
\hline $\mathrm{M}$ & AURKA & $\mathrm{y}$ & $\mathrm{x}$ & 46,306 & 1,522 & 3,234 & 5,797 & 6790 \\
\hline M & CCNA2 & $\mathrm{y}$ & & 31,573 & 344 & 1,538 & 2,710 & 890 \\
\hline
\end{tabular}


Table 1 (continued)

\begin{tabular}{|c|c|c|c|c|c|c|c|c|}
\hline \multirow[t]{2}{*}{ Cell cycle stage } & \multirow[t]{2}{*}{ Gene name } & \multirow[t]{2}{*}{${ }^{\mathrm{a}} \mathrm{CC}$} & \multirow[t]{2}{*}{${ }^{\mathrm{b}} \mathrm{M}$} & \multicolumn{4}{|c|}{ Microarray fluorescence units } & \multirow[t]{2}{*}{ Entrez gene ID } \\
\hline & & & & 8Cell (Ave) & Fibro & iPS & hES (Ave) & \\
\hline M & $\mathrm{CDC} 20$ & $\mathrm{y}$ & $\mathrm{x}$ & 29,105 & 688 & 4,203 & 5,406 & 991 \\
\hline M & CENPE & $\mathrm{y}$ & & 7,700 & 755 & 1,972 & 3,390 & 1062 \\
\hline M & CIT & $\mathrm{y}$ & & 356 & 3,871 & 1,749 & 4,732 & 11113 \\
\hline M & KIF23 & $\mathrm{y}$ & & 22,920 & 1,600 & 4,376 & 5,526 & 9493 \\
\hline M & ORC1L & $\mathrm{y}$ & $\mathrm{x}$ & 2,007 & 66 & 812 & 1,326 & 4998 \\
\hline \multicolumn{9}{|c|}{ Cycle in primary fibroblasts } \\
\hline $\mathrm{S}$ & GMNN & $\mathrm{y}$ & $\mathrm{x}$ & 62,273 & 2,432 & 9,468 & 19,070 & 51053 \\
\hline G2 & UBE2C & $\mathrm{y}$ & $\mathrm{x}$ & 144,929 & 2,903 & 12,472 & 28,375 & 11065 \\
\hline $\mathrm{M}$ & CCNB1 & $\mathrm{y}$ & $\mathrm{x}$ & 156,398 & 4,004 & 13,791 & 19,417 & 891 \\
\hline M & CKS1B & $\mathrm{y}$ & $\mathrm{x}$ & 87,120 & 5,491 & 20,061 & 33,098 & 1163 \\
\hline M & PTTG1 & $\mathrm{y}$ & $\mathrm{x}$ & 579,305 & 15,479 & 31,030 & 41,398 & 9232 \\
\hline M & SKP2 & $\mathrm{y}$ & $\mathrm{x}$ & 26,057 & 159 & 1,139 & 1,873 & 6502 \\
\hline
\end{tabular}

${ }^{\mathrm{a}}$ Known cell cycle gene

${ }^{\mathrm{b}}$ Myc target $(27,28)$

(Table 1): CDC6, an essential DNA replication licensing factor; CHAF1A, chromatin assembly factor 1, part of a nuclear complex that assembles histones onto newly replicated DNA; and RRM2, ribonucleotide reductase 2, a well known rate-limiting enzyme for DNA replication. The two genes whose knock-down blocked G2 in both HeLa and U20S, CDC2 (CDK1, cyclin dependent kinase), and PLK1 (pololike kinase 1), were both over-detected on the 8-Cell and hES gene arrays relative to fibroblasts. Both $\mathrm{Cdc} 2$ and Plk1 have numerous roles in cell cycle progression [34, 35].

Six cycling genes were needed for mitosis in both cell types, one of which, AURKB, was $>10$-fold over-detected on the 8-Cell arrays relative to all other cell types (Table 1). Aurora kinase B is a chromosomal passenger protein whose expression for normal cytokinesis is tightly controlled: over-expression or under-expression leads to centrosome amplification, defects in spindle formation, and multinucleation [36]. Four of the six cycling mitosis genes were over-detected on both 8 -Cell and hES arrays relative to fibroblasts: CDCA8 (borealin), ESPL1 (separase), FBX05 (Emi1) and TPX2. Borealin is a chromosomal passenger protein required for stability of the bipolar mitotic spindle [37] and recently reported to be essential for cleavage from the 2-cell to 4-cell stage of mouse embryos [38]; separase cleaves cohesin to allow the separation of sister chromatids [39] and cleaves the linker between mother and daughter centrioles to license centriole duplication [40]; Emil represses $\mathrm{APC} / \mathrm{C}^{\mathrm{cdh} 1}$ in $\mathrm{G} 2$ [36], thus blocking the degradation of Cyclin $\mathrm{A},-\mathrm{B}$ and geminin, and allowing both the formation of new DNA replication initiation sites and the prevention of re-replication of DNA before mitosis. Emi1 is essential for mouse embryo development beyond the blastocyst stage [41] and for normal development in zebrafish [42]. Failure to degrade Emil in prophase leads to "mitotic catastrophe", including centrosome overduplication [41]. Tpx2 is expressed exclusively at the G1/S transition and throughout $\mathrm{G} 2$ and activates Aurora kinase $\mathrm{A}$ on centrosomes to assemble mitotic spindles [43, 44].

Cell cycle genes identified by RNA knock-down in U20S and HeLa

Fifty three gene elements were identified as inhibiting cell cycle progression in both the U2OS and HeLa cells, but were not identified as cycling by the primary fibroblast study. Only 12 DAVID-mapped to cell cycle or DNA metabolism, suggesting the discovery of many new genes important for cell cycle progression that may not have redundant functions and that should be GO designated cell cycle. Interestingly, several were not detected above background levels in 8CFES (Tables S1-S3). Twenty were reported targets of Myc [39, 40]. Eleven genes arrested G1, 10 arrested S phase, 10 arrested G2, and 22 arrested mitosis.

KCNH5 (Eag2), one of the knocked-down genes that arrested both cell types in G1, was markedly over-detected on the 8-Cell arrays (Table 1, and 2), but nearly silent on all other 8 CFES arrays. Eag2 is an outwardly rectifying voltage-gated potassium channel recently shown to bind to alpha and beta-tubulin [45] suggesting it may play an important role in the cytoskeleton of the large 8-cell blastomeres. Knock-down of RKHD2 (MEX3C), the human homolog of the $\mathrm{C}$. elegans Mex-3 gene, arrested U20S in G1 and HeLa cells in S phase. One allele of 
Table 2 Functional categories of cell cycle genes

\begin{tabular}{|c|c|c|c|c|c|c|}
\hline \multirow[t]{2}{*}{ Gene name } & \multicolumn{3}{|c|}{ Expression } & \multirow[t]{2}{*}{ Entrez gene ID } & \multirow[t]{2}{*}{ Known CC } & \multirow[t]{2}{*}{ Myc target } \\
\hline & 8C Over & 8C,hES Over & 8C Under & & & \\
\hline \multicolumn{7}{|c|}{ Cyclin, cyclin-dependent kinase (cdk), cdk-inhibitor } \\
\hline CCNE1 & $\mathrm{x}$ & & & 898 & $\mathrm{y}$ & $\mathrm{x}$ \\
\hline $\mathrm{CDC} 25 \mathrm{~B}$ & $\mathrm{x}$ & & & 994 & $\mathrm{y}$ & \\
\hline CCNA1 & $\mathrm{x}$ & & & 8900 & $\mathrm{y}$ & \\
\hline CCNA2 & & $\mathrm{x}$ & & 890 & $\mathrm{y}$ & \\
\hline CCNB1 & $\mathrm{x}$ & & & 891 & $\mathrm{y}$ & $\mathrm{x}$ \\
\hline CCNB3 & $\mathrm{x}$ & & & 85417 & $\mathrm{y}$ & \\
\hline CCND1 & & & $\mathrm{x}$ & 595 & $\mathrm{y}$ & $\mathrm{x}$ \\
\hline CDC2 & & $\mathrm{x}$ & & 983 & $\mathrm{x}$ & \\
\hline CDC2L1 & $\mathrm{x}$ & & & 984 & $\mathrm{y}$ & \\
\hline CDKN1A, -B & & & $\mathrm{x}$ & 1026 & $\mathrm{y}$ & \\
\hline CRKRS & $\mathrm{x}$ & & & 51755 & & $\mathrm{x}$ \\
\hline CDK6 & & & $\mathrm{x}$ & 1021 & $\mathrm{y}$ & $\mathrm{x}$ \\
\hline \multicolumn{7}{|c|}{ Kinase, kinase inhibitor, phosphatase } \\
\hline AURKA,-B & $\mathrm{x}$ & & & 6790,9212 & $\mathrm{y}$ & $\mathrm{x}$ \\
\hline AURKC & $\mathrm{x}$ & & & 6795 & $\mathrm{y}$ & \\
\hline BUB1,-1B & & $\mathrm{x}$ & & 699,701 & $\mathrm{y}$ & $\mathrm{x}$ \\
\hline CKS1B & & $\mathrm{x}$ & & 1163 & $\mathrm{y}$ & $\mathrm{x}$ \\
\hline MAPK4(ERK3) & $\mathrm{x}$ & & & 5596 & & \\
\hline NEK2 & $\mathrm{x}$ & & & 4751 & $\mathrm{y}$ & $\mathrm{x}$ \\
\hline PPMID & $\mathrm{x}$ & & & 8493 & $\mathrm{y}$ & $\mathrm{x}$ \\
\hline PLK1 & & $\mathrm{x}$ & & 5347 & $\mathrm{y}$ & \\
\hline PRKD2 & & $\mathrm{x}$ & & 25865 & & \\
\hline SKP2 & $\mathrm{x}$ & & & 6502 & $\mathrm{y}$ & $\mathrm{x}$ \\
\hline WEE1 & & & $\mathrm{x}$ & 7465 & $\mathrm{y}$ & $\mathrm{x}$ \\
\hline \multicolumn{7}{|c|}{ Transcription, translation } \\
\hline E2F3 & & & $\mathrm{x}$ & 1871 & $\mathrm{y}$ & $\mathrm{x}$ \\
\hline MYC & $\mathrm{x}$ & & & 4609 & $\mathrm{y}$ & \\
\hline $\mathrm{RB}$ & & & $\mathrm{x}$ & 5925 & $\mathrm{y}$ & $\mathrm{x}$ \\
\hline RBBP4 & & $\mathrm{x}$ & & 5928 & $\mathrm{y}$ & $\mathrm{x}$ \\
\hline RBBP6 & $\mathrm{x}$ & & & 5930 & & \\
\hline RBM14 & & $\mathrm{x}$ & & 10432 & $\mathrm{y}$ & $\mathrm{x}$ \\
\hline RKHD2 & $\mathrm{x}$ & & & 51320 & & $\mathrm{x}$ \\
\hline \multicolumn{7}{|c|}{ DNA replication, chromosome duplication, cohesin } \\
\hline CDCA8(borealin) & & $\mathrm{x}$ & & 55143 & $\mathrm{y}$ & $\mathrm{x}$ \\
\hline CDC6 & & $\mathrm{x}$ & & 990 & $\mathrm{y}$ & $\mathrm{x}$ \\
\hline CHAF1A & & $\mathrm{x}$ & & 10036 & $\mathrm{y}$ & $\mathrm{x}$ \\
\hline CDC45L & & $\mathrm{x}$ & & 8318 & $\mathrm{y}$ & \\
\hline CDT1 & & $\mathrm{x}$ & & 81620 & $\mathrm{y}$ & $\mathrm{x}$ \\
\hline DTL & & $\mathrm{x}$ & & 51514 & $\mathrm{y}$ & $\mathrm{x}$ \\
\hline ESPL1(separase) & & $\mathrm{x}$ & & 9700 & $\mathrm{y}$ & $\mathrm{x}$ \\
\hline GINS2,-3 & & $\mathrm{x}$ & & 51659,64785 & $\mathrm{y}$ & \\
\hline GINS4 & $\mathrm{x}$ & & & 84296 & $\mathrm{y}$ & \\
\hline GMNN & & $\mathrm{x}$ & & 51053 & $\mathrm{y}$ & $\mathrm{x}$ \\
\hline H1FO & $\mathrm{x}$ & & & 3005 & $\mathrm{y}$ & \\
\hline HJURP & & $\mathrm{x}$ & & 55355 & & \\
\hline NPAT & $\mathrm{x}$ & & & 4863 & $\mathrm{y}$ & \\
\hline
\end{tabular}


Table 2 (continued)

\begin{tabular}{|c|c|c|c|c|c|c|}
\hline \multirow[t]{2}{*}{ Gene name } & \multicolumn{3}{|c|}{ Expression } & \multirow[t]{2}{*}{ Entrez gene ID } & \multirow[t]{2}{*}{ Known CC } & \multirow[t]{2}{*}{ Myc target } \\
\hline & 8C Over & 8C,hES Over & 8C Under & & & \\
\hline ORC1L & & $\mathrm{x}$ & & 4998 & $\mathrm{y}$ & $\mathrm{x}$ \\
\hline PCNA & & $\mathrm{x}$ & & 5111 & $\mathrm{y}$ & $\mathrm{x}$ \\
\hline POLS & $\mathrm{x}$ & & & 11044 & $\mathrm{y}$ & $\mathrm{x}$ \\
\hline PTTG1,-3 & $\mathrm{x}$ & & & 9232,26255 & $\mathrm{y}$ & \\
\hline PTTG2 & $\mathrm{x}$ & & & 10744 & $\mathrm{y}$ & \\
\hline RFC3 & & $\mathrm{x}$ & & 5983 & $\mathrm{y}$ & \\
\hline RRM2 & $\mathrm{x}$ & & & 6241 & $\mathrm{y}$ & $\mathrm{x}$ \\
\hline TERF1 & & & $\mathrm{x}$ & 7013 & $\mathrm{y}$ & \\
\hline TIPIN & & $\mathrm{x}$ & & 54962 & $\mathrm{y}$ & $\mathrm{x}$ \\
\hline STAG3,-3L3 & $\mathrm{x}$ & & & 10734,442578 & $\mathrm{y}$ & $\mathrm{x}$ \\
\hline \multicolumn{7}{|c|}{ Centrosome, centriole, securin, spindle } \\
\hline CENPE & & $\mathrm{x}$ & & 1062 & $\mathrm{y}$ & \\
\hline $\mathrm{CDC} 20$ & & $\mathrm{x}$ & & 991 & $\mathrm{y}$ & $\mathrm{x}$ \\
\hline DLG7 & $\mathrm{x}$ & & & 9787 & $\mathrm{y}$ & \\
\hline INCENP & $\mathrm{x}$ & & & 3619 & $\mathrm{y}$ & $\mathrm{x}$ \\
\hline TPX2 & & $\mathrm{x}$ & & 22974 & $\mathrm{y}$ & \\
\hline \multicolumn{7}{|c|}{ Ion channel, structural protein, other } \\
\hline AVPI1 & $\mathrm{x}$ & & & 60370 & $\mathrm{y}$ & $\mathrm{x}$ \\
\hline BARD1 & & $\mathrm{x}$ & & 580 & $\mathrm{y}$ & $\mathrm{x}$ \\
\hline CABYR & $\mathrm{x}$ & & & 26256 & & \\
\hline FBXO5(EMI1) & & $\mathrm{x}$ & & 26271 & $\mathrm{y}$ & $\mathrm{x}$ \\
\hline KCNH5 & $\mathrm{x}$ & & & 27133 & & \\
\hline KIF23 & & $\mathrm{x}$ & & 9493 & $\mathrm{y}$ & \\
\hline KIFC1 & & & & & $\mathrm{y}$ & $\mathrm{x}$ \\
\hline LMNB2 & & & $\mathrm{x}$ & 84823 & & $\mathrm{x}$ \\
\hline CUL2,-5 & $\mathrm{x}$ & & & 8453,8065 & $\mathrm{y}$ & \\
\hline CIT & & & $\mathrm{x}$ & 11113 & $\mathrm{y}$ & \\
\hline REEP4 & $x$ & & & 80346 & & \\
\hline
\end{tabular}

RKHD2 was also markedly over-detected on the 8Cell arrays (Table 1) which is especially interesting because in combination with CUL2 (encodes the ubiquitin ligase also over-detected on the 8-Cell arrays), it has important roles in anterior-posterior cell partitioning in C. elegans embryos [46]. Only CUL2, not RKHD2 nor KCNH5, DAVIDmapped to cell cycle.

Knockdown of a cytochrome B-like gene (CYB561D1) and a CDC2-related kinase, CRKRS (CRK7), the exact functions of which are unknown, blocked mitosis in both U20S and HeLa and did not DAVID-map to cell cycle. CYB561D1 was detected at higher levels on the 8-Cell and hES cell arrays than either the fibroblast or iPS cell arrays (Table S3), whereas CRKRS was detected at higher levels on the 8-Cell arrays than all other cell types (Table 1).

Not surprising, knock-down of INCENP, inner centromere passenger protein, blocked mitosis in both U20S and
HeLa, but it was surprisingly over-detected in 8-Cells relative to the other cell types, especially fibroblasts and iPS cells. In mammalian cells, 2 broad groups of centromere-interacting proteins have been described: constitutively binding centromere proteins and 'passenger,' or transiently interacting, proteins. The constitutive proteins are encoded by CENPA, -B, -C1 and -PD, none of which were identified by the RNA knock-down studies (Table S1). The term 'passenger proteins' encompasses a broad collection of proteins that localize to the centromere during specific stages of the cell cycle [47, 48]. These include CENPE and -F, cytoplasmic dyneins (e.g. DYNC1LI2, DYNLL1, DYNLRB1, Table S1) and INCENP. The passenger proteins display a broad localization along chromosomes in the early stages of mitosis but gradually become concentrated at centromeres as the cell cycle progresses into mid-metaphase. During telophase, the 
proteins are located within the midbody in the intercellular bridge, where they are discarded after cytokinesis. INCENP and CENPE knockout mice die at peri-implantation stage [49].

Cell cycle genes identified by RNA knock-down in U20S cells and cycle in fibroblasts

Eighteen genes were detected by knock-down in U2OS and also cycled in primary fibroblasts (Tables S1 and S3), of which 12 had previously been designated GO term cell cycle. Four blocked G1, two blocked S phase, four arrested G2, and eight blocked mitosis. Eleven are known cell cycle genes and seven are Myc targets.

Knock-down of BUB1brought about a G1 arrest in the U20S cells, a surprise because this gene encodes a kinase involved in spindle checkpoint activation, suggesting it plays a role in $\mathrm{M}$ phase. Mutations in this kinase, overdetected in 8-Cells, iPS cells and hES cells relative to fibroblasts, have been associated with aneuploidy and several forms of cancer [50].

One of the cycling genes in this group whose knockdown blocked U20S cells in S phase, GINS2, part of the DNA replication initiation complex, was over-detected on 8-Cells and hES cells, and one, KIFC1, a kinesin family member central to chromosome congression [51], was markedly over-detected on the 8-Cell arrays (Table 1). Only one of the knocked-down genes in this group that blocked U20S cells in G2 was over-expressed in the 8Cells, CABYR, a calcium-binding protein, which did not DAVID-map to cell cycle. Originally thought to be testis specific, and a marker for testis cancer, several non-testis variants of this gene have been described [52]. CDKN1B (p27) was under-detected specifically on the 8-Cell arrays, thus removing another potential cell cycle block.

Of the 8 cycling genes in this group whose knock-down blocked mitosis, two were over-detected in 8Cells and hES cells, BARD1 and PRKD2, and two were over-detected specifically in 8Cells, CDC25B and REEP4. Bard1 is important to centrosome duplication and mitotic spindle assembly [53], and essential for mouse embryo development [54]; PRKD2 is a serine/threonine protein kinase about which little is known. CDC25B activates the cyclin dependent kinase CDC2 (CDK1) and is required for entry into mitosis; REEP4 is a membrane receptor accessory protein about which little is known.

Cell cycle genes identified by RNA knock-down in HeLa cells and cycle in fibroblasts

Fifty six genes were identified in the HeLa cells that also cycled in the synchronized primary fibroblasts (Tables S1 and S3), 32 of which DAVID-mapped to cell cycle, and 17 of which were identified as Myc targets. Fifteen blocked G1, 16 blocked S phase, five blocked G2, and 19 blocked mitosis.

Of the 15 cycling genes that blocked G1 progression in HeLa when knocked-down, two were over-detected on the 8-Cell arrays, CCNE1 and RBBP6, and two, HJURP and NEK2 were over-detected on both 8-Cells and hES cells. RBBP6 (retinoblastoma binding protein 6) is a multifunctional protein known to have $\mathrm{Rb}$-independent activities [55]. The over-expression of HJURP, Holliday junctionrecognizing protein, suggests the 8 -Cells and hES cells may invoke a response to DNA double-strand breaks first described for cancer cells that prevents apoptosis in response to DNA damage and continues cell cycling [56]. Recent work suggests HJURP stabilizes Cenp A, the anchor protein for centrosome formation, and is therefore important for normal cytokinesis $[57,58]$. NEK2 encodes a kinetochore-associated protein kinase that stabilizes chromosome attachment to spindle microtubules [59].

Of the 16 knocked-down genes that blocked HeLa in S phase, three were over-detected on the 8-Cell and hES cell arrays relative to fibroblasts, BUB1B, NPAT and PCNA, and one was markedly under-detected, LMNB2. Bub1B (BubR1) is a critical member of the spindle assembly checkpoint [60]. NPAT is an essential member of the p220 (NPAT)/HiNF-P pathway, controlled by CyclinE/Cdk2, which activates histone $\mathrm{H} 4$ gene expression, essential to accurate packaging of newly synthesized DNA into chromatin [61]. PCNA, proliferating cell nuclear antigen, is a member of the DNA sliding clamp family, forming a trimeric, head to tail ring around helical DNA. It is a processivity factor for DNA polymerase delta, and also has other functions in cell cycle control [62, 63].

The under-expression of LMNB2 specifically in the 8Cells is intriguing. The lamins, $\mathrm{A} / \mathrm{C}, \mathrm{B} 1$ and $\mathrm{B} 2$, are intermediate filament proteins that make up the nuclear matrix next to the inner nuclear membrane. During mitosis, the lamina matrix is reversibly disassembled as the lamin proteins are phosphorylated. Structural assessment of various combinations of lamins $\mathrm{A} / \mathrm{C}, \mathrm{B} 1$ and $\mathrm{B} 2$ indicated polymers with B2 were "weaker" than those with B1 [64]. LmnB1 mRNA was detected on the 8CFES arrays at approximately the same level as the iPS and hES cells, all at higher levels than the fibroblasts. This suggests that the 8 Cell nuclear lamina matrix may be comprised principally of LmnB1. The LMNB2 gene sequence is also a known origin of replication site, and given the rapid cell cycles of early embryos, the gene may be bound by DNA replication initiation factors nearly without interruption [65].

Of the five cycling knocked-down genes that blocked HeLa in G2, two were over-detected on the 8Cell and hES arrays: DTL, the Cdt1-targeting component of one of the ubiquitin ligases (CUL4-DDB1) responsible for degrada- 
tion of Cdt1 during $\mathrm{S}$ phase to prevent re-replication of DNA [66], and TIPIN, encodes a replication fork binding partner of Timeless [67]. H1F0, an oocyte-specific replacement linker histone [68], was over-detected specifically on the 8-Cell array.

Of the 19 knocked-down genes that blocked HeLa in mitosis, one was over-detected on the 8-Cell arrays, AURKA, and five were over-detected on the 8-Cell and hES arrays: CCNA2, CDC20, CENPE, KIF23, and ORC1L, and one was markedly under-detected on the 8Cell arrays, CIT, a citron kinase essential for normal cytokinesis in neuronal progenitor cells [69]. Aurora kinase $\mathrm{A}$ is involved in centrosome and spindle assembly and activates Plk1 at the G2/M transition [70]. Over activation of either, or both, is linked to cancer development [70]. $\operatorname{Ccd} 20$ is a regulatory subunit of anaphase promoting complex, $\mathrm{APC} / \mathrm{C}$, and may play a more important role in early embryo cells [71] than in somatic cells [72]; CenpE, centrosome protein E, and KIF23, are both kinesin-like motor proteins that play a role in chromosome movement $[51,73]$; and Orc1l is the largest subunit of the Orc1 complex essential for the initiation of DNA replication and recently shown to also play a key role in controlling centriole and centrosome copy number in human cells [74].

Interestingly, several well described cell cycle genes shown to cycle in the primary fibroblasts were not detected by the knock-down strategies, including GMNN and CKS1B, and UBE2C over-detected on both the 8-Cell and hES arrays, and CCNB1, PTTG1 (securin) and SKP2, overdetected specifically on the 8-Cell arrays. Geminin prevents re-replication of DNA during S phase [75]; Cks1B is a kinase that blocks the inhibition of Cdks by $\mathrm{p} 27$ (CDKN1B) [76]. UBE2C encodes a ubiquitin-conjugating enzyme that specializes in targeting cyclins, especially G1 cyclins, for proteolysis [77]; Cyclin B1 stimulates Cdk1 during $\mathrm{G} 2$, and has multiple roles in the $\mathrm{G} 2$ to $\mathrm{M}$ transition [78]; securin is best known for inhibition of separase (Espl1), the enzyme that allows the separation of sister chromatids, for most of the cell cycle [79]; Skp2 is a wellstudied component of a ubiquitin ligase that targets Cyclin E and p27 for proteolysis [80].

\section{Conclusions}

Using public databases of gene ontologies, combined with a gene assembly derived from high-throughput RNA knockdown and cell synchronization studies, we have identified 35 cell cycle genes over-detected on whole human genome microarrays of 8-cell stage blastomeres, 31 genes overdetected on both 8-Cell and hES microarrays, and ten genes under-detected on 8-Cell arrays (Table 2). This is by no means a comprehensive list of genes important to the cell cycle of totipotent and pluripotent cells because of the significant number of genes with unknown function, the relatively conservative ( \pm 7 -fold) criteria for classification of over- or under-detection, and the lack of verification that the microarray results reflect protein expression. It does, however, lay groundwork essential for the design of the targeted experiments possible with the small numbers of human embryos available for research.

Whether or not the genes are known targets of Myc (14 of the 35 genes over-detected on the 8-Cell arrays, 18 of the 31 over-detected on both the 8-Cell and hES arrays, and five of the ten genes under-detected on the 8-Cells) did not predict level of detection on the microarrays despite the relatively high level of detection of MYC on the 8-Cell arrays. This may relate to the observation that association with multiple transcription factors in addition to Myc correlated with high level of expression in embryonic stem cells [29].

The 8-Cell blastomere is only one or two cell cycles away from initial commitment to either outer trophoblast cells, or inner cell mass cells. That commitment carries with it a new dependence upon growth factors, such as fibroblast growth factor and insulin, for both cell lineages [81-83], in keeping with the detection of RB1 on the hES cell microarrays [1] and in mouse blastocysts [6]. Most of the daughter cells of the 8-Cell blastomere will commit to trophoblast, only a few to inner cell mass. Trophoblast stem cells will in turn undergo commitment to placenta, including initiating cycles of endoreduplication of the genome without cytokinesis, characteristic of placental cells [84].

The functions of 16 of the 35 genes over-detected on the 8-Cell arrays: AURKC, AVPI1, CABYR, CCNA1, CCNB3, CDC2L1, CRKRS, CUL2, KIFC1, RBBP6, RKHD2, PTTG2, -3, REEP4, STAG3, -3L3, are poorly understood and urgently in need of additional study. The functions in the 8-Cell blastomeres of the 19 better studied genes over-detected on the 8-Cell arrays: CCNE1, CDC25B, CCNB1, AURKA, -B, MAPK4, SKP2, MYC, NPAT, POLS, PTTG1, RRM2, DLG7, INCENP, KCNH5, PPM1D, GINS4, H1F0, and KIFC1 are also not known with certainty, although some predictions are possible.

The lack of $\mathrm{Rb}$ and Wee1 is similar to the absence of cell cycle checkpoints in frog embryos [24], relieves the 8-Cells from growth factor dependence for the G1 to S transition, and is consistent with the over-expression of CCNE1 and CCNA1, -2 factors essential for the $\mathrm{G} 1$ to $\mathrm{S}$ transition. RB1 was also silent, and Wee1 at threshold level of detection, on the microarrays of ovulated metaphase II human oocytes [31], indicating that unlike mouse embryos [6], these two genes are not among those that undergo degradation the first few days after fertilization of human eggs [85]. If checkpoint control in early human embryos is analogous to 
frog embryo development, RB and WEE1 may be turned on at the blastocyst stage, as evidenced by their detection on the hES cell microarrays [1], and those cells with abnormal karyotype or errors in DNA replication may undergo programmed cell death [22-24].

Three other genes over-detected on the 8-Cells that were either not detected, or detected at very low levels in the human oocytes [31] are INCENP, KCNH5 and CCNA1, indicating these genes must also be upregulated following fertilization. In contrast, CCNE1, PTTG, and STAG3 were readily detected on the oocyte arrays, suggesting maternal messages could be still detected in the 8-Cells.

Frog embryo survival depends on becoming motile as quickly as possible after fertilization. Human embryo survival depends on sending immediate, sufficient and increasing molecular signals to the mother that development is progressing, or menses ensues. One obvious mechanism for accomplishing these goals is rapid duplication of gene copies early in development, which is more easily accomplished if cell cycle checkpoints are silent, and cell cycle drivers are over-expressed. But subsequent development requires faithful duplication and allocation of chromosomes, so how does the early embryo accomplish both?

Clues from the microarray data suggest G1 and S phase progression are augmented by ample Cyclin E, Cyclin A1, -2 and key DNA replication factors, such as ribonucleotide reductase and DNA polymerase $\mathrm{S}$, thought to push strand synthesis through cohesin sites, Npat, important for chromatin organization, and Hjurp, thought to block cell cycle arrest by DNA strand breaks. Robust expression of geminin and its protector, Emil, may prevent DNA rereplication errors. $\mathrm{G} 2$ to $\mathrm{M}$ phase is rushed by ample expression of Cyclin A and Cyclin B, Cdc25B, and elements important to timely proteolysis, Ube2C and Skp2, to allow the transition to metaphase. Attempts to ensure the integrity of chromosome allocation to daughter blastomeres include over-expression of chromosome glue, including Incenp and Stag proteins, as well as Pttg proteins to block separase (Espl1) activity and prevent pre-mature chromosome separation. Especially noteworthy on the 8-cell arrays are the high levels of detection of the Aurora kinase family, A, B and C, major players in centrosome duplication and formation of the mitotic spindle, as well as kinesins, KIFC1 and KIF23.

Taken together, the lack of well described cell cycle checkpoints in the presence of robust expression of cell cycle drivers and their controls in the 8-Cell blastomeres, suggest more dependence upon accurate cycling of gene expression, perhaps regulated by circadian oscillators [1], for faithful daughter cell formation than on the checkpoints imposed by growth factor dependency of later stage cells. This would have the advantage of rapid gene duplication, but the disadvantage of cleavage mishaps resulting from even slightly out of phase or inappropriate abundance of gene expression. The phenomenon of identical twinning indicates that only half of early cleavage cells are needed for viable offspring, suggesting at least half of the blastomeres could be genetically defective without dire consequences. Studies of the relative expression in individual normal and abnormal human embryos of the genes identified by this analysis of 8-Cell blastomere gene expression will reveal which cycling elements are the most critical for development.

Acknowledgements This work was supported by the Bedford Research Foundation, Naylor Fund for Stem Cell Research, and special account (vat\#090145420) for research grants of the National and Kapodistian University of Athens.

Open Access This article is distributed under the terms of the Creative Commons Attribution Noncommercial License which permits any noncommercial use, distribution, and reproduction in any medium, provided the original author(s) and source are credited.

\section{References}

1. Kiessling AA, Bletsa R, Desmarais B, Mara C, Kallianidis K, Loutradis D. Evidence that human blastomere cleavage is under unique cell cycle control. J Assist Reprod Genet. 2009;26:187-95.

2. Nichols KE, Walther S, Chao E, Shields C, Ganguly A. Recent advances in retinoblastoma genetic research. Curr Opin Ophthalmol. 2009;20:351-5.

3. Sage J, Mulligan GJ, Attardi LD, Miller A, Chen S, Williams B, et al. Targeted disruption of the three Rb-related genes leads to loss of G(1) control and immortalization. Genes Dev. 2000;14:3037-50.

4. Hardy K, Spanos S. Growth factor expression and function in the human and mouse preimplantation embryo. J Endocrinol. 2002;172:221-36.

5. Kiessling AA, Davis HW, Williams CS, Sauter RW, Harrison LW. Development and DNA polymerase activities in cultured preimplantation mouse embryos: comparison with embryos developed in vivo. J Exp Zool. 1991;258:34-47.

6. Iwamori N, Naito K, Sugiura K, Tojo H. Preimplantation-embryospecific cell cycle regulation is attributed to the low expression level of retinoblastoma protein. FEBS Lett. 2002;526:119-23.

7. Kiessling AA, Anderson S, Kiessling AA, Anderson S. Human embryonic stem cells. 2nd ed. Sudbury: Jones and Bartlett; 2007.

8. Ferguson RL, Maller JL. Cyclin E-dependent localization of MCM5 regulates centrosome duplication. J Cell Sci. 2008;121: 3224-32.

9. Geng Y, Yu Q, Sicinska E, Das M, Schneider JE, Bhattacharya S, et al. Cyclin E ablation in the mouse. Cell. 2003;114:431-43.

10. Hwang HC, Clurman BE. Cyclin E in normal and neoplastic cell cycles. Oncogene. 2005;24:2776-86.

11. O'Connell MJ, Raleigh JM, Verkade HM, Nurse P. Chk1 is a wee1 kinase in the G2 DNA damage checkpoint inhibiting cdc2 by Y15 phosphorylation. EMBO J. 1997;16:545-54.

12. Bielanska M, Tan SL, Ao A. Chromosomal mosaicism throughout human preimplantation development in vitro: incidence, type, and relevance to embryo outcome. Hum Reprod. 2002;17:413-9.

13. Dupont C, Segars J, Decherney A, Bavister BD, Armant DR, Brenner CA. Incidence of chromosomal mosaicism in morphologically normal nonhuman primate preimplantation embryos. Fertil Steril 2009. 
14. Marquez C, Sandalinas M, Bahce M, Alikani M, Munne S. Chromosome abnormalities in 1255 cleavage-stage human embryos. Reprod Biomed Online. 2000;1:17-26.

15. Miller BH, McDearmon EL, Panda S, Hayes KR, Zhang J, Andrews JL, et al. Circadian and CLOCK-controlled regulation of the mouse transcriptome and cell proliferation. Proc Natl Acad Sci USA. 2007;104:3342-7.

16. Yagita K, Tamanini F, van Der Horst GT, Okamura H. Molecular mechanisms of the biological clock in cultured fibroblasts. Science. 2001;292:278-81.

17. Tsinkalovsky O, Smaaland R, Rosenlund B, Sothern RB, Hirt A, Steine $\mathrm{S}$, et al. Circadian variations in clock gene expression of human bone marrow CD34+ cells. J Biol Rhythms. 2007;22:14050 .

18. Matsuo T, Yamaguchi S, Mitsui S, Emi A, Shimoda F, Okamura H. Control mechanism of the circadian clock for timing of cell division in vivo. Science. 2003;302:255-9.

19. Dekens MP, Whitmore D. Autonomous onset of the circadian clock in the zebrafish embryo. EMBO J. 2008;27:2757-65.

20. Kiessling AA, Weitlauf HM. DNA polymerase activity in preimplantation mouse embryos. J Exp Zool. 1979;208:347-54.

21. Luna M, Copperman AB, Duke M, Ezcurra D, Sandler B, Barritt J. Human blastocyst morphological quality is significantly improved in embryos classified as fast on day 3 ( $>$ or $=10$ cells), bringing into question current embryological dogma. Fertil Steril. 2008;89:358-63.

22. Hardy K, Stark J, Winston RM. Maintenance of the inner cell mass in human blastocysts from fragmented embryos. Biol Reprod. 2003;68:1165-9.

23. Jurisicova A, Varmuza S, Casper RF. Programmed cell death and human embryo fragmentation. Mol Hum Reprod. 1996;2:93-8.

24. Carter AD, Wroble BN, Sible JC. Cyclin A1/Cdk2 is sufficient but not required for the induction of apoptosis in early Xenopus laevis embryos. Cell Cycle. 2006;5:2230-6.

25. Bar-Joseph Z, Siegfried Z, Brandeis M, Brors B, Lu Y, Eils R, et al. Genome-wide transcriptional analysis of the human cell cycle identifies genes differentially regulated in normal and cancer cells. Proc Natl Acad Sci USA. 2008;105:955-60.

26. Kittler R, Pelletier L, Heninger AK, Slabicki M, Theis M, Miroslaw L, et al. Genome-scale RNAi profiling of cell division in human tissue culture cells. Nat Cell Biol. 2007;9:1401-12.

27. Mukherji M, Bell R, Supekova L, Wang Y, Orth AP, Batalov S, et al. Genome-wide functional analysis of human cell-cycle regulators. Proc Natl Acad Sci USA. 2006;103:14819-24.

28. Kidder BL, Yang J, Palmer S. Stat3 and c-Myc genome-wide promoter occupancy in embryonic stem cells. PLoS ONE. 2008;3: e3932.

29. Kim J, Chu J, Shen X, Wang J, Orkin SH. An extended transcriptional network for pluripotency of embryonic stem cells. Cell. 2008;132:1049-61.

30. Loutradis D BR, Mara K, Drakakis P, Stefanidis K, Kiessling A. A program of human egg and embryo donation for gene expression analysis. In: International Society for Stem Cell Research. Cairnes; 2007.

31. Kocabas AM, Crosby J, Ross PJ, Otu HH, Beyhan Z, Can H, et al. The transcriptome of human oocytes. Proc Natl Acad Sci USA. 2006; 103:14027-32.

32. Takahashi K, Tanabe K, Ohnuki M, Narita M, Ichisaka T, Tomoda $\mathrm{K}$, et al. Induction of pluripotent stem cells from adult human fibroblasts by defined factors. Cell. 2007;131:861-72.

33. Tesar PJ, Chenoweth JG, Brook FA, Davies TJ, Evans EP, Mack DL, et al. New cell lines from mouse epiblast share defining features with human embryonic stem cells. Nature. 2007;448:196-9.

34. Baker DJ, Dawlaty MM, Galardy P, van Deursen JM. Mitotic regulation of the anaphase-promoting complex. Cell Mol Life Sci. 2007;64:589-600.
35. Murray AW. Recycling the cell cycle: cyclins revisited. Cell. 2004;116:221-34

36. You J, Li Q, Wu C, Kim J, Ottinger M, Howley PM. Regulation of aurora $\mathrm{B}$ expression by the bromodomain protein $\mathrm{Brd} 4$. Mol Cell Biol. 2009;29:5094-103.

37. Gassmann R, Carvalho A, Henzing AJ, Ruchaud S, Hudson DF, Honda R, et al. Borealin: a novel chromosomal passenger required for stability of the bipolar mitotic spindle. J Cell Biol. 2004;166:179-91.

38. Zhang Q, Lin G, Gu Y, Peng J, Nie Z, Huang Y, et al. Borealin is differentially expressed in ES cells and is essential for the early development of embryonic cells. Mol Biol Rep. 2009;36:603-9.

39. Yuan K, Li N, Huo Y, Yan F, Yang Y, Ward T, et al. Recruitment of separase to mitotic chromosomes is regulated by Aurora B. Cell Cycle. 2009;8:1433-43.

40. Sun Y, Kucej M, Fan HY, Yu H, Sun QY, Zou H. Separase is recruited to mitotic chromosomes to dissolve sister chromatid cohesion in a DNA-dependent manner. Cell. 2009;137:123-32.

41. Lee H, Lee DJ, Oh SP, Park HD, Nam HH, Kim JM, et al. Mouse emi1 has an essential function in mitotic progression during early embryogenesis. Mol Cell Biol. 2006;26:5373-81.

42. Rhodes J, Amsterdam A, Sanda T, Moreau LA, McKenna K, Heinrichs S, et al. Emil maintains genomic integrity during zebrafish embryogenesis and cooperates with p53 in tumor suppression. Mol Cell Biol. 2009;29:5911-22.

43. Bird AW, Hyman AA. Building a spindle of the correct length in human cells requires the interaction between TPX2 and Aurora A. J Cell Biol. 2008;182:289-300.

44. Schatz CA, Santarella R, Hoenger A, Karsenti E, Mattaj IW, Gruss OJ, et al. Importin alpha-regulated nucleation of microtubules by TPX2. EMBO J. 2003;22:2060-70.

45. Bracey K, Ju M, Tian C, Stevens L, Wray D. Tubulin as a binding partner of the heag2 voltage-gated potassium channel. J Membr Biol. 2008;222:115-25.

46. Buchet-Poyau K, Courchet J, Le Hir H, Seraphin B, Scoazec JY, Duret L, et al. Identification and characterization of human Mex-3 proteins, a novel family of evolutionarily conserved RNA-binding proteins differentially localized to processing bodies. Nucleic Acids Res. 2007;35:1289-300.

47. Earnshaw WC, Mackay AM. Role of nonhistone proteins in the chromosomal events of mitosis. FASEB J. 1994;8:947-56.

48. Jeyaprakash AA, Klein UR, Lindner D, Ebert J, Nigg EA, Conti E. Structure of a Survivin-Borealin-INCENP core complex reveals how chromosomal passengers travel together. Cell. 2007;131:27185.

49. Cutts SM, Fowler KJ, Kile BT, Hii LL, O’Dowd RA, Hudson DF, et al. Defective chromosome segregation, microtubule bundling and nuclear bridging in inner centromere protein gene (Incenp)disrupted mice. Hum Mol Genet. 1999;8:1145-55.

50. Klebig C, Korinth D, Meraldi P. Bub1 regulates chromosome segregation in a kinetochore-independent manner. J Cell Biol. 2009;185:841-58.

51. Cai S, O'Connell CB, Khodjakov A, Walczak CE. Chromosome congression in the absence of kinetochore fibres. Nat Cell Biol. 2009; 11:832-8.

52. Hsu HC, Lee YL, Cheng TS, Howng SL, Chang LK, Lu PJ, et al. Characterization of two non-testis-specific CABYR variants that bind to GSK3beta with a proline-rich extensin-like domain. Biochem Biophys Res Commun. 2005;329:1108-17.

53. Ryser S, Dizin E, Jefford CE, Delaval B, Gagos S, Christodoulidou $\mathrm{A}$, et al. Distinct roles of BARD1 isoforms in mitosis: fulllength BARD1 mediates Aurora B degradation, cancer-associated BARD1beta scaffolds Aurora B and BRCA2. Cancer Res. 2009;69:1125-34.

54. McCarthy EE, Celebi JT, Baer R, Ludwig T. Loss of Bard1, the heterodimeric partner of the Brcal tumor suppressor, results in 
early embryonic lethality and chromosomal instability. Mol Cell Biol. 2003;23:5056-63.

55. Pugh DJ, Ab E, Faro A, Lutya PT, Hoffmann E, Rees DJ. DWNN, a novel ubiquitin-like domain, implicates RBBP6 in mRNA processing and ubiquitin-like pathways. BMC Struct Biol. 2006;6:1.

56. Kato T, Sato N, Hayama S, Yamabuki T, Ito T, Miyamoto M, et al. Activation of Holliday junction recognizing protein involved in the chromosomal stability and immortality of cancer cells. Cancer Res. 2007;67:8544-53.

57. Dunleavy EM, Roche D, Tagami H, Lacoste N, Ray-Gallet D, Nakamura Y, et al. HJURP is a cell-cycle-dependent maintenance and deposition factor of CENP-A at centromeres. Cell. 2009;137: 485-97.

58. Foltz DR, Jansen LE, Bailey AO, Yates 3rd JR, Bassett EA, Wood $\mathrm{S}$, et al. Centromere-specific assembly of CENP-a nucleosomes is mediated by HJURP. Cell. 2009;137:472-84.

59. Du J, Cai X, Yao J, Ding X, Wu Q, Pei S, et al. The mitotic checkpoint kinase NEK2A regulates kinetochore microtubule attachment stability. Oncogene. 2008;27:4107-14.

60. Izumi H, Matsumoto Y, Ikeuchi T, Saya H, Kajii T, Matsuura S. BubR1 localizes to centrosomes and suppresses centrosome amplification via regulating Plk1 activity in interphase cells. Oncogene. 2009;28:2806-20.

61. Xie R, Medina R, Zhang Y, Hussain S, Colby J, Ghule P, et al. The histone gene activator HINFP is a nonredundant cyclin E/ CDK2 effector during early embryonic cell cycles. Proc Natl Acad Sci USA. 2009;106:12359-64.

62. Gilljam KM, Feyzi E, Aas PA, Sousa MM, Muller R, Vagbo CB, et al. Identification of a novel, widespread, and functionally important PCNA-binding motif. J Cell Biol. 2009;186:645-54.

63. Naryzhny SN, Zhao H, Lee H. Proliferating cell nuclear antigen (PCNA) may function as a double homotrimer complex in the mammalian cell. J Biol Chem. 2005;280:13888-94.

64. Schirmer EC, Gerace L. The stability of the nuclear lamina polymer changes with the composition of lamin subtypes according to their individual binding strengths. J Biol Chem. 2004;279:42811-7.

65. Paixao S, Colaluca IN, Cubells M, Peverali FA, Destro A, Giadrossi S, et al. Modular structure of the human lamin B2 replicator. Mol Cell Biol. 2004;24:2958-67.

66. Sansam CL, Shepard JL, Lai K, Ianari A, Danielian PS, Amsterdam A, et al. DTL/CDT2 is essential for both CDT1 regulation and the early G2/M checkpoint. Genes Dev. 2006;20:3117-29.

67. Yoshizawa-Sugata N, Masai H. Human Tim/Timeless-interacting protein, Tipin, is required for efficient progression of $\mathrm{S}$ phase and DNA replication checkpoint. J Biol Chem. 2007;282:2729-40.

68. Tsunemoto K, Anzai M, Matsuoka T, Tokoro M, Shin SW, Amano T, et al. Cis-acting elements (E-box and NBE) in the promoter region of three maternal genes (Histone H1oo, Nucleoplasmin 2, and Zygote Arrest 1) are required for oocyte-specific gene expression in the mouse. Mol Reprod Dev. 2008;75:1104-8.
69. Paramasivam M, Chang YJ, LoTurco JJ. ASPM and citron kinase co-localize to the midbody ring during cytokinesis. Cell Cycle. 2007;6:1605-12.

70. Macurek L, Lindqvist A, Medema RH. Aurora-A and hBora join the game of Polo. Cancer Res. 2009;69:4555-8.

71. Li M, York JP, Zhang P. Loss of Cdc20 causes a securindependent metaphase arrest in two-cell mouse embryos. Mol Cell Biol. 2007;27:3481-8.

72. Baumgarten AJ, Felthaus J, Wasch R. Strong inducible knockdown of APC/CCdc20 does not cause mitotic arrest in human somatic cells. Cell Cycle. 2009;8:643-6.

73. Liu X, Zhou T, Kuriyama R, Erikson RL. Molecular interactions of Polo-like-kinase 1 with the mitotic kinesin-like protein $\mathrm{CHO} 1 /$ MKLP-1. J Cell Sci. 2004;117:3233-46.

74. Hemerly AS, Prasanth SG, Siddiqui K, Stillman B. Orc1 controls centriole and centrosome copy number in human cells. Science. 2009;323:789-93.

75. Zhu W, Depamphilis ML. Selective killing of cancer cells by suppression of geminin activity. Cancer Res. 2009;69:4870-7.

76. Wang XC, Tian J, Tian LL, Wu HL, Meng AM, Ma TH, et al. Role of Cks1 amplification and overexpression in breast cancer. Biochem Biophys Res Commun. 2009;379:1107-13.

77. Walker A, Acquaviva C, Matsusaka T, Koop L, Pines J. UbcH10 has a rate-limiting role in G1 phase but might not act in the spindle checkpoint or as part of an autonomous oscillator. J Cell Sci. 2008;121:2319-26.

78. Hong KU, Kim HJ, Kim HS, Seong YS, Hong KM, Bae CD, et al. Cdk1-cyclin B1-mediated phosphorylation of tumor-associated microtubule-associated protein/cytoskeleton-associated protein 2 in mitosis. J Biol Chem. 2009;284:16501-12.

79. Vlotides G, Eigler T, Melmed S. Pituitary tumor-transforming gene: physiology and implications for tumorigenesis. Endocr Rev. 2007;28:165-86.

80. Hu R, Aplin AE. Skp2 regulates G2/M progression in a p53dependent manner. Mol Biol Cell. 2008;19:4602-10.

81. Cowan CA, Klimanskaya I, McMahon J, Atienza J, Witmyer J, Zucker JP, et al. Derivation of embryonic stem-cell lines from human blastocysts. N Engl J Med. 2004;350:1353-6.

82. Simmons DG, Cross JC. Determinants of trophoblast lineage and cell subtype specification in the mouse placenta. Dev Biol. 2005;284:12-24.

83. Thomson JA, Itskovitz-Eldor J, Shapiro SS, Waknitz MA, Swiergiel JJ, Marshall VS, et al. Embryonic stem cell lines derived from human blastocysts. Science. 1998;282:1145-7.

84. Ullah Z, Kohn MJ, Yagi R, Vassilev LT, DePamphilis ML. Differentiation of trophoblast stem cells into giant cells is triggered by p57/Kip2 inhibition of CDK1 activity. Genes Dev. 2008;22:3024-36.

85. Dobson AT, Raja R, Abeyta MJ, Taylor T, Shen S, Haqq C, et al. The unique transcriptome through day 3 of human preimplantation development. Hum Mol Genet. 2004;13:1461-70. 